\title{
Shopper typologies amongst a Generation $Y$ consumer cohort and variations in terms of age in the fashion apparel market
}

\author{
Authors: \\ Chengedzai Mafini ${ }^{1}$ \\ Manillall Dhurup ${ }^{1}$ \\ Lawrence Mandhlazi ${ }^{1}$ \\ Affiliations: \\ ${ }^{1}$ Faculty of Management \\ Sciences, Vaal University of \\ Technology, South Africa \\ Correspondence to: \\ Chengedzai Mafini \\ Email: \\ chengedzai@hotmail.com \\ Postal address: \\ Private Bag X021, \\ Vanderbijlpark 1900, \\ South Africa \\ Dates: \\ Received: 01 July 2013 \\ Accepted: 29 Oct. 2013 \\ Published: 02 Apr. 2014 \\ How to cite this article: \\ Mafini, C., Dhurup, M. \\ \& Mandhlazi, L., 2014, \\ 'Shopper typologies amongst \\ a Generation Y consumer \\ cohort and variations in \\ terms of age in the fashion \\ apparel market', Acta \\ Commercii 14(1), Art. \#209, \\ 11 pages. http://dx.doi. \\ org/10.4102/ac.v14i1.209

\section{Copyright:} \\ (C) 2014. The Authors. \\ Licensee: AOSIS \\ OpenJournals. This work \\ is licensed under the \\ Creative Commons \\ Attribution License.
}

Read online:

Scan this QR code with your smart phone or mobile device to read online.
Purpose: The primary purpose of the study was to examine Generation Y consumer shopper typologies. The secondary purpose was to establish the influence of age in the identified shopper typologies.

Rational: Marketers have ever been concerned with the behaviour of consumers. Generation Y consumers have emerged as an important marketing segment. Consequently, a need exists to investigate behavioural issues pertaining to this age cohort on a continuous basis.

Methodology: A survey questionnaire was administered to a convenient sample of 230 Generation Y consumers of fashion apparel. Exploratory factor analysis was used to identify shopper typologies. The Kruskal-Wallis test was used to examine the influence of age on the identified shopper typologies.

Findings: The study identified seven shopper typologies that are applicable to the Generation Y cohort. These are quality conscious, brand conscious, novelty seeking, hedonistic, confused by over-choice, habitual, brand loyal and fashion conscious shopper typologies. The study also revealed that younger consumers were found to be more confused by over-choice than their older counterparts.

Value of research: These findings may enable marketers to understand and predict the purchase behaviour of Generation Y consumers, thereby facilitating the development and implementation of more effective marketing strategies.

\section{Introduction}

Over the past two decades, Generation Y consumers have become an important marketing segment in the global marketplace (Noble, Haytko \& Phillips 2009). This can be attributed to the fact that individuals in this age group are in the marketplace in great numbers and have purchasing power that surpasses that of any other group of consumers (Morton 2002). Generation Y individuals have grown up in a consumption-driven contemporary society and have more money at their disposal than any teen group in history (Kennedy 2001). This makes them arguably the largest group of consumers in any economy (Chaston 2009), to the extent that they merit close attention from both marketing practitioners and empirical researchers (Branchik 2010).

Since generations are different, it is important for marketers to treat individuals and groups of different age cohorts differently (Rempel 2009). In finding new ways to market to Generation Y, it is essential for marketers to have a clear and distinct conceptualisation of these consumers, by being constantly aware of the changing attitudes and trends in this generation (Hughes 2008). Rapid technological changes make it crucial to examine the consumer behaviour of Generation $Y$ continuously. This is supposedly because as soon as one perceives that one has an understanding of what this group wants, those wants will have changed (Kaltcheva \& Weitz 2006). Generation Y consumers typically spend their cash promptly after acquiring it, usually on consumer goods and personal services (McKay 2008). Additionally, compared with their predecessors, Generation Y consumers are more likely to be involved in compulsive and impulse buying (Rosenburg 2008). Moreover, in their quest for uniqueness, they are usually disposed to have doubts about the stores that their parents shop in (Branchik 2010).

In recent times, generational cohorts have emerged as a helpful tool in explaining the tectonic shifts in buying behaviour amongst various consumer groups. A generational cohort may be perceived as a collection of individuals who have experienced a common social, political, historical and economic environment (Neal, Quester \& Hawkins 2004). This development has led to the emergence and widespread use of the phrase 'Generation $Y^{\prime}$ to identify a particular group of individuals. Generation $\mathrm{Y}$ individuals are also labelled the Millennium Generation, 
Echo Boomers, Why Generation, Net Generation, Gen Wired, We Generation, DotNet, Ne(x)t Generation, Nexters, First Globals, iPod Generation, and iYGeneration (Koutras 2006; Williams \& Page 2011). Whilst experts differ on the exact start and end dates of this age cohort, following on the logic that baby boomers are those individuals born between 1946 and 1964 and Generation X those born between 1965 and 1979 (Schiffman \& Kanuk 2010), the starting date for Generation Y is taken as 1980. The end date of this cohort is taken as 1994 (Kotler 2003; Schiffman \& Kanuk ibid).

Generation Ys were born during the period when countries could easily communicate with one another, especially with the surfacing of direct means of communication, which is characterised by a powerful convergence towards materialism (Cant, Brink \& Brijball 2006). Generation Y consumers tend to be far more diverse than the generations before them, because they have extreme confidence, awareness and individuality (Laermer \& Simmons 2007). They also have a more optimistic viewpoint and are more socially conscious and open to new experiences (Truman 2007). Additionally, they display the need to be in constant connection and communication with their peers (Cortes 2004). This generation, contrary to popular belief, leads a relatively quiet life of listening to music and hanging out with friends (Bush, Martin \& Bush 2004). They have also moved some of their television viewing habits to the Internet and are less likely to read the newspaper than their parents are (Cant et al. ibid).

Against this backdrop, this study explored the shopper typologies that are applicable to Generation $\mathrm{Y}$ consumers. For the purposes of the current study, shopper typologies of Generation $\mathrm{Y}$ consumers were considered within the context of the fashion apparel market. The fashion apparel context was selected because of the fact that Generation $Y$ consumers tend to exhibit an appetite for fashion apparel (Williams \& Page 2011). Since they are fashion conscious, Generation Y consumers typically spend two-thirds of their income on fashion apparel (Bakewell \& Mitchell 2003; Kim \& Park 2005). As suggested by a number of scholars (Chaston 2009; Liljander, Polsa \& Van Riel 2009; Pentecost \& Lynda 2010; Schewe \& Meredith 2004), Generation Y consumers tend to be more fascinated by fashion apparel, fast foods and electronic gadgets than by other commodities. This gave an impetus for this study to be conducted within the ambit of the fashion apparel market.

\section{Consumer shopper typologies}

Research reveals that at various levels of marketing theory and practice, the consumer is central to all activities. It is important for marketers to have an updated knowledge of the various factors influencing the decisions of consumers in order to facilitate both the successful delivery of products as well as the retention of customers in the marketplace (Hollywood, Armstrong \& Durkin 2007). Shopper typologies define general consumer types, such as price-oriented shoppers, problem-solving shoppers, impulse shoppers and convenience shoppers (Zeng 2008). The shopper typologies approach seeks to categorise consumers into groups or types that are related to retail patronage (Leo, Bennett \& Hartel 2005) as well as shopping orientations (Gehrt \& Shim 1998).

Shopping orientations are shoppers' styles that place special emphasis on certain activities (Gehrt \& Shim 1998). Shopping orientation is recognised as a complex social, cultural and economic phenomenon (Lee 1998). As such, the examination of an all-inclusive relationship amongst key variables in determining shopping orientations could provide diagnostic value to retailers in determining market segmentation (Hou \& Lin 2004; Lee ibid). The basic premise of shopping orientation is that shoppers with different styles have different market behaviours, including a need for different information sources and different store preferences (Gehrt \& Shim ibid).

It is well established that the first taxonomy of consumer shopping typologies was suggested by Westbrook and Black (1985), and attempted to improve the understanding of motivation-based shopper typologies of adult female shoppers in department stores. This taxonomy stratified shopping styles into four classifications: the economic consumer, the personalising consumer, the ethical consumer and the apathetic consumer. Economic shoppers are characterised by a cautious approach to shopping, giving heightened attention to merchandise assortment, price and quality. Personalising shoppers are those who seek personal relationships with retail personnel, whilst ethical shoppers are those who are willing to forgo lower prices and wider selections of goods in order to behave consistently with their moral beliefs. Finally, apathetic shoppers are those who purchase goods largely out of necessity, with the shopping activity holding no intrinsic interest.

Hafstrom, Chae and Chung (1992) examined the taxonomy of shoppers, and identified 'perfectionism', 'value consciousness', 'brand consciousness', 'novelty-fad-fashion consciousness', 'shopping avoider-time saver-satisfier', and 'confused supportseeking decision-maker' as the dominant shopping orientations amongst consumers. In this taxonomy, perfectionist consumers seek the very best quality products, have high standards and expectations for consumer goods and are concerned with the function and quality of products. Valueconscious consumers are low price conscious, look for the best value for their money and are likely to be comparison shoppers. Brand-conscious consumers are oriented toward expensive and well-known national brands and feel price is an indicator of quality. Novelty-fad-fashion-conscious consumers gain excitement and pleasure from seeking out new things and are conscious of the new fashions and fads. Shopping avoider-time saver-satisfier consumers avoid shopping, make shopping trips rapidly and may forgo some quality for time and convenience. Finally, the confused support-seeking decision-maker finds the marketplace confusing; they view brands as alike and seek help from friends to make decisions (Hafstrom et al. ibid).

Bae (2004) distinguished eight characteristics of consumer shopping orientations: perfectionist, brand conscious, 
novelty/fashion conscious, recreational/hedonic, price conscious/value-for-money, impulsive/careless, confused by over-choice and habitual/loyal consumers. The perfectionist or quality-conscious consumers have a desire for highquality products and a need to make the best or perfect choice versus buying the first product or brand that is available. The brand-conscious consumer has the desire to purchase wellknown national brands, higher-priced brands or the most advertised brands. The novelty/fashion-conscious consumer can be defined as a shopper who is aware of new styles, changing fashions and attractive styling, as well as having the desire to buy something exciting. The recreational/ hedonic consumers are shoppers who enjoy shopping as a leisure-time activity. The price-conscious consumers aspire towards the best value, buying at sale prices or the lowest price. The impulsive/careless consumers can be described as shoppers who tend to make impulsive, unplanned and careless purchases. The consumer confused by over-choice feels confused by product choices because of a proliferation of brands, stores and consumer information. Finally, the habitual/brand-loyal consumers are described as consumers who have favourite brands and whose buying habits reveal that they consistently use the same store over time (Bae 2004).

Based on the preceding discussion, it can be concluded that there is diversity in consumer shopping typologies. Consumers tend to display different shopping orientations, based upon their individual personalities and characteristics (Bae 2004). They may have a unique focus when they enter a store and shop (McDonald 1993). Some consumers consider a good price and trendy fashion, whilst others are interested in brand names with high quality. Depending on their wants, consumers customise their shopping orientations. Consumer confusion, however, often takes over when they encounter other choices immediately prior to making a specific selection (Mishra 2010).

\section{Shopper typologies and variations in terms of age}

The shopping behaviour of consumers is influenced by a number of factors. Jackson et al. (2001) opine that internal conditions such as demographics (e.g. gender and age), psychographics (lifestyle), personality, motivation, knowledge, attitudes, beliefs and feelings play an influential role in shaping the behaviour of consumers. Blackwell, Miniard and Engel (2006) also posit that psychological factors, which include an individual's motivation, perception, attitude and beliefs, are also important antecedents to a consumer's buying decision. Personal factors, which include income level, personality, age, occupation and lifestyle, have also been found to be important determinants of an individual's shopping orientations (Foxall 2005). With regard to the influence of age in determining shopping orientations, Kinley, Josiam and Lockett (2010) noted that people change the goods and services they buy over their lifetimes. For example, teenagers would be more interested in buying bright and loud colours compared to a middle aged or elderly individual, who would prefer decent and subtle designs (Blackwell et al. ibid). Additionally, a young single person would hardly be interested in buying a house, property, insurance policies or to invest in gold (Schwartz 2004). It appears, then, that age is an enduring determinant of consumer purchase orientation (Foxall ibid). However, it is interesting to note that the influence of age is restricted to people in different age groups. Some scholars (e.g. Gupta, Brantley \& Vanessa 2010; Kim \& Kim 2004) note that the influence of age on the shopping orientations of individuals within the same generational cohort is limited. More precisely, a recent study by Valentine and Thomas (2013) reveals that Generation Y consumer purchase decisions are not influenced by age. Therefore, based on the aforementioned insights, the following hypothesis is formulated:

$\mathbf{H}_{1}$ : There are no significant differences between shopper typologies of the Generation $Y$ cohort and the age of respondents.

\section{Problem statement}

The subject of fundamental determinants of consumer behaviour has been a topical issue amongst researchers and marketers for many years (Bakewell \& Mitchell 2003). According to Jin and Kim (2003), consumers tend to display differrent shopping orientations and this provokes the need for more elaborate empirical introspection. More specifically, Generation Y consumers have been brought up in an era when shopping has migrated from being a simple act of buying to a highly complex and sophisticated process (Bakewell \& Mitchell ibid). There are a number of reasons for conducting this study. Firstly, Generation Ys may have developed shopping orientations that are different from those of previous generations (Bakewell \& Mitchell ibid; Ma \& Niehm 2006). Secondly, shopping orientations are an important factor to researchers and marketing practitioners alike, as evidenced through the extensive attention that the subject has received. As observed by Noble et al. (2009), there is a need to conduct more research on a regular basis to understand the trends in the fast-evolving Generation $\mathrm{Y}$ market. Thirdly, empirical evidence on this subject in the context of South African Generation Y consumers is generally lacking. It is therefore important that the shopping orientations of Generation Y consumers be investigated in order to close this gap in research.

In the light of the preceding assertions, the primary objective of the study was to establish the shopper typologies applicable to Generation Y consumers. The secondary objective of the study was to determine whether the identified Generation $Y$ consumers' shopping orientations varied based on their ages. The study is significant in that its findings may be used to assist marketers to develop and implement strategies that are appropriate in meeting the needs of the Generation $\mathrm{Y}$ group of consumers.

\section{Research methodology Respondents}

The sample used in the current study was composed of 230 Generation Y individuals. Respondents were recruited from 
different shopping malls through intercept interviews in the Kempton Park area of Gauteng, South Africa. Kempton Park was chosen because of its economic significance to South Africa. For instance, the area boasts a multiracial society with a population of nearly 200000 people, houses the largest airport in Africa, O.R. Tambo International Airport, and has a large and active industrial site and advanced retailing infrastructure in the form of shopping malls and shopping centres (City of Ekurhuleni 2011). In addition, it is interesting to note that the sample size of 230 Generation $\mathrm{Y}$ consumers is consistent with previous studies (Bakewell \& Mitchell 2004; Drake-Bridges \& Burgess 2010; Durvasula, Lysonski \& Andrews 1993; Kim 2003; Kwan, Yeung \& Au 2008), in which similar sample sizes were used to investigate the behaviour of Generation Y consumers, albeit in different contexts. Generation $\mathrm{Y}$ individuals also possess the mental and cognitive capacity to respond to questionnaire-type questions (Shoham \& Dalakas 2003). Furthermore, for exploratory factor analysis (EFA), Everett (1975) advocates that the ratio of sample size to number of items should be $1: 10$, although in some cases the minimum of four times the number of items is considered acceptable, depending on how closely items are related to the construct. However, if the sample taps the construct, the required sample size can be less than the ratio of 1:10. In line with this view, some scholars (e.g. MacCallum et al. 1999; Matsunaga 2010) affirm that if there are five or more items tapping the same factor, a sample size in the region of 200 may be sufficient. Based on these suggestions and samples used by previous researchers who have conducted research on Generation Y consumers, the sample size was considered adequate to conduct the analysis.

\section{Data collection and measuring instrument}

In the current study, a structured self-administered survey questionnaire was used to collect the data. Structured questionnaires are advantageous in that they are versatile and facilitate the accurate collection of data, since all respondents are asked the same questions (Tustin et al. 2005). The questionnaire was compiled using Likert scales adapted from previous relevant research studies (Bakewell \& Mitchell 2003; Durvasula et al. 1993; Fan \& Xiao 1998; Gutman \& Mills 1982; Hafstrom et al. 1992; Leo et al. 2005; McDonald 1993; Oh \& Fiorito 2002; Parker, Hermans \& Schaefer 2004; Sproles $\&$ Kendall 1986). The questions were developed with a fivepoint Likert scale, anchored by 5 denoting strongly agree, 3 denoting moderately agree and 1 denoting strongly disagree. The Likert scale was used because it is relatively easy to construct and makes data easy to collect and analyse, thereby making it suitable for surveys (DeVellis 2003; Kothari 2009).

The questionnaire was divided into two sections. Section A consisted of questions related to shopping orientations. Section B elicited respondents' demographic information. After its construction, the questionnaire was pretested in a conveniently selected sample of 20 respondents in order to identify and eliminate problems as well as to determine the time for the completion of the questionnaire (Presser et al. 2004). Feedback from the pretest sample was used to make minor revisions to the questionnaire (Radhakrishna 2007). Thereafter, the questionnaire was administered on four consecutive weekends (Saturdays and Sundays) in April 2012. Weekends were selected as they are the busiest shopping days of the week in South Africa (Bowles 2012). The shoppers were requested to complete the questionnaires after they had completed their shopping for the day so that valid measures of the time spent could be elicited (Da-Silva, Davies \& Naude 2002; Dhurup 2008). Three trained undergraduate third-year marketing students from a South African university of technology assisted in the administration of the questionnaires. During the process of data collection, the research assistants were monitored on-site by the principal researcher. A covering letter that clearly specified that anonymity of the respondents would be guaranteed and that the study was purely for academic purposes was attached to the questionnaire. Of the 350 questionnaires that were initially administered, 263 were returned. Of these, 33 were eliminated because they were incomplete, which resulted in the 230 questionnaires used in the current study.

\section{Analysis of results}

In the current study, the collected data were analysed using the Statistical Packages for the Social Sciences (SPSS version 21.0). The empirical results obtained are presented in this section as follows: the characteristics of the sample are reported, followed by a report on the validity and reliability of the scale. The results of the factor analysis of the shopper typologies of Generation $\mathrm{Y}$ consumer decision-making styles are then presented, followed by the results of the study's examination of whether there were any significant differences between the established shopping styles and the ages of respondents.

\section{Sample composition}

The gender distribution in the sample indicates that out of 230 respondents, 78 were male (34\%) and 152 were female (66\%). The age group 16-20 years formed the highest percentage (49\%), followed by the age group $21-24$ years (35\%) and the age group $25-27$ years (16\%). In terms of race, $86 \%$ (198) of the respondents were Black people, $8 \%(18)$ were White people, $4 \%$ (9) were Indian people and $2 \%$ (5) were Mixed race.

\section{Factor analysis}

The shopper typologies of Generation Y consumers were determined using exploratory factor analysis, which was conducted using principal component analysis with varimax rotation and Kaiser normalisation. Since exploratory factor analysis is used to identify a set of latent (hidden) constructs underlying a battery of measured variables (Norris \& Lecavalier 2009), it was, in this study, performed with a view to condensing the experimental variables into identifiable shopper typologies.

To determine whether the data were suitable for factor analysis, Bartlett's test of sphericity and the Keiser- 
Meyer-Olkin (KMO) measure of sampling adequacy were conducted, as recommended by Pett, Lackey and Sullivan (2003). Bartlett's test of sphericity was significant at $p<$ 0.000 , from which it could be inferred that the data set was not an identity matrix with zero correlations and was suitable for factor analysis (Aldlaign \& Buttle 2002). The KMO measure of sampling adequacy was 0.894 , which is considered satisfactory by Malhotra (2009), signifying that the data were suitable for factor analysis. The percentage of variance explained, the scree plot and eigenvalue criterion guided the extraction of factors. In addition, items that loaded heavily (cross-loadings) on more than one factor were eliminated from further scale refinement. Items were eliminated either because of cross-loading or low factor loading $(<0.50)$ (Maholtra 2007). This procedure resulted in the removal of five variables from the original data set. Seven meaningful factors were extracted and labelled fashion-conscious consumers, hedonistic consumers, brandconscious consumers, novelty-seeking consumers, qualityconscious consumers, consumers who are confused by overchoice, and habitual, brand-loyal consumers. A summary of the factors, their respective descriptions and the cumulative percentage of variance are reported in Table 1 . The seven factors accounted for approximately $71 \%$ of the explained variance, which is considered acceptable (Malhotra 2009).

\section{Reliability and validity}

The Cronbach's alpha statistic was computed to assess the internal consistency of the instrument (Leo et al. 2005). Reliability tests were conducted on all 41 items. The items that had low or negative inter-item correlations were deleted. Table 2 reports the Cronbach's alpha values for the seven dimensions of Generation Y shopper typologies. The Cronbach's alpha coefficients for all seven factors ranged from 0.836 to 0.961 , indicating satisfactory levels of internal consistency in terms of reliability. The seven factors reflected reliability values above the accepted benchmark of 0.70, which, according to Hair et al. (2010), is regarded as satisfactory. In addition, the reliability of the overall scale was 0.891 , which was also considered satisfactory.

In the present study, Bae's (2004) conceptualisation of validity, as the degree to which a test or instrument measures what it purports to measure, was adopted. Content validity was ascertained in the pretest. To test for content validity,
20 respondents were chosen to participate in the pretest. The inter-item correlation was examined in order to identify low or negative correlations amongst variables that measured decision-making styles. Subsequently, changes were made to the questionnaire, where several items were deleted, added or re-worded in order to capture the essence of Generation $\mathrm{Y}$ consumer decision-making within the context of fashion apparel retailing. Construct validity of the scale was assessed by the computation of the Cronbach's alpha coefficient for the scale and sub-dimensions of the scale, which were all acceptable and served as indications of construct validity (Parasuraman, Zeithaml \& Berry 1988).

\section{Confirmatory factor analysis and goodness of fit measures}

In accordance with the procedure suggested by Anderson and Gerbing (1988), a confirmatory factor analysis (CFA) was performed to further examine reliability and convergent and discriminant validity of the multi-item construct measures using AMOS 21.0. Overall acceptable model fit was indicated by goodness-of-fit index (GFI) $\geqq 0.80$, adjusted goodness-of fit index (AGFI) $\geqq 0.80$, root mean square error of approximation (RMSEA) values $\leqq 0.08$, incremental index of fit (IFI), Tucker-Lewis index (TLI) and comparative fit index (CFI) values $\geqq 0.90$ and Chi-square degrees of freedom ratio $(\mathrm{CMIN} / \mathrm{DF})$ value $<3$. Recommended statistics for the final overall model assessment show acceptable fit of the measurement model to the data: CMIN/DF $=1088.204 / 758$ $=1.436, \mathrm{GFI}=0.932 ; \mathrm{AGFI}=0.920, \mathrm{IFI}=0.948, \mathrm{TLI}=0.940$, $\mathrm{CFI}=0.947, \mathrm{RMSEA}=0.044$. Table 2 summarises the means, reliability and accuracy statistics through a confirmatory factors analysis approach.

An analysis of Table 2 reveals that the individual item loadings are all above the recommended 0.5 level (Anderson \& Gerbing 1988), indicating acceptable individual item reliabilities as more than $50 \%$ of each item's variance is shared with its respective construct. Composite reliabilities (CR) and average variance extracted (AVE) for each construct were also computed using the formula proposed by Fornell and Larcker (1981). The CR values are all above the recommended value of 0.7 suggested by Hulland (1999), thus indicating acceptable internal consistency and reliability of the respective measures. All AVE values were above 0.5 , thus acceptable according to literature (Fraering \& Minor 2006).

TABLE 1: Factors, descriptions of factors and cumulative percentage of variance extracted.

\begin{tabular}{|c|c|c|}
\hline Factors label & Factor description & $\%$ of variance \\
\hline Fashion conscious & A characteristic representing a consumer who is motivated to keep up to date with styles and fashion trends. & 27.014 \\
\hline Hedonistic & A characteristic measuring the degree to which a consumer finds shopping activity enjoyable and shops for the fun of it. & 11.184 \\
\hline Brand conscious & Measuring a consumer's orientation to buying the more expensive, well-known brands. & 9.278 \\
\hline Novelty seeking & $\begin{array}{l}\text { A characteristic identifying consumers who appear to like new and innovative products and gain excitement from seeking } \\
\text { new products. }\end{array}$ & 7.365 \\
\hline Quality conscious & $\begin{array}{l}\text { A characteristic measuring the degree to which a consumer searches carefully and systematically for the best quality in } \\
\text { products. }\end{array}$ & 5.413 \\
\hline Confused by over-choice & $\begin{array}{l}\text { A characteristic identifying those consumers who perceive too many brands and stores from which to choose, } \\
\text { experiencing information overload in the market. }\end{array}$ & 5.212 \\
\hline Habitual, brand loyal & A characteristic indicating consumers who have favourite brands and stores, who have formed habits around these. & 5.131 \\
\hline \multicolumn{2}{|c|}{ Cumulative $\%$ of variance explained } & 70.597 \\
\hline
\end{tabular}


TABLE 2: Means, reliability and accuracy analysis statistics.

\begin{tabular}{|c|c|c|c|c|c|c|c|}
\hline \multirow[t]{2}{*}{ Constructs and brief descriptions } & \multirow[t]{2}{*}{ Means } & \multicolumn{2}{|c|}{ Cronbach's tests } & \multirow[t]{2}{*}{ CR value } & \multirow[t]{2}{*}{ AVE value } & \multirow{2}{*}{$\begin{array}{c}\text { Shared } \\
\text { variance }\end{array}$} & \multirow{2}{*}{$\begin{array}{l}\text { Factor } \\
\text { loadings: }\end{array}$} \\
\hline & & $\begin{array}{l}\text { Item-total } \\
\text { correlations }\end{array}$ & $\alpha$ values $\dagger$ & & & & \\
\hline Construct 1: Fashion-conscious consumers & 3.86 & - & 0.961 & 0.98 & 0.97 & 0.22 & - \\
\hline I am an experienced user of fashion clothing. & 3.16 & .838 & - & - & - & - & 0.851 \\
\hline Fashion clothing is a significant part of my life. & 3.10 & .802 & - & - & - & - & 0.820 \\
\hline I usually dress for fashion. & 3.91 & .836 & - & - & - & - & 0.852 \\
\hline I go shopping to keep up with the trends. & 3.11 & .753 & - & - & - & - & 0.770 \\
\hline I am very familiar with fashion clothing. & 3.33 & .820 & - & - & - & - & 0.841 \\
\hline I feel I know a lot about fashion clothing. & 3.97 & .855 & - & - & - & - & 0.875 \\
\hline I would classify myself as an expert on fashion clothing. & 2.96 & .818 & - & - & - & - & 0.838 \\
\hline For me fashion clothing is an important product. & 3.22 & .853 & - & - & - & - & 0.871 \\
\hline Construct 2: Hedonistic consumers & 3.11 & - & 0.927 & 0.93 & 0.93 & 0.08 & - \\
\hline Shopping for clothing is not a pleasant activity for me. & 2.73 & .668 & - & - & - & - & 0.664 \\
\hline I enjoy shopping just for the fun of it. & 3.01 & .665 & - & - & - & - & 0.654 \\
\hline I do my shopping quickly. & 3.14 & .737 & - & - & - & - & 0.755 \\
\hline I don't waste my time just shopping. & 3.23 & .817 & - & - & - & - & 0.872 \\
\hline Shopping for clothing wastes my time. & 3.13 & .781 & - & - & - & - & 0.825 \\
\hline It is worth my time to shop in these stores. & 3.16 & .812 & - & - & - & - & 0.878 \\
\hline Shopping for clothing satisfies my sense of curiosity. & 3.28 & .816 & - & - & - & - & 0.873 \\
\hline Construct 3: Brand-conscious consumers & 3.67 & - & 0.875 & 0.91 & 0.89 & 0.12 & - \\
\hline The higher the price of clothing, the better the quality. & 3.93 & .697 & - & - & - & - & 0.747 \\
\hline $\begin{array}{l}\text { Nice departments and speciality stores offer me the best } \\
\text { clothing. }\end{array}$ & 3.71 & .656 & - & - & - & - & 0.706 \\
\hline The most advertised brands are usually very good choices. & 3.47 & 686 & - & - & - & - & 0.738 \\
\hline The well-known brands of clothing are best for me. & 3.58 & .700 & - & - & - & - & 0.761 \\
\hline $\begin{array}{l}\text { The more expensive brands of clothing are usually purchased } \\
\text { by choice. }\end{array}$ & 3.75 & .656 & - & - & - & - & 0.705 \\
\hline I keep my wardrobe up to date with the changing fashion. & 3.45 & .750 & - & - & - & - & 0.801 \\
\hline Fashionable, attractive styling is very important for me. & 3.16 & .784 & - & - & - & - & 0.863 \\
\hline $\begin{array}{l}\text { To get variety, I shop at different stores and choose different } \\
\text { brands. }\end{array}$ & 3.47 & .719 & - & - & - & - & 0.785 \\
\hline It's fun to buy new clothing. & 3.83 & .756 & - & - & - & - & 0.789 \\
\hline It's fun to buy exciting clothing. & 3.71 & .669 & - & - & - & - & 0.706 \\
\hline Construct 5: Quality-conscious consumers & 4.26 & - & 0.846 & 0.90 & 0.87 & 0.12 & - \\
\hline Getting very good quality is important to me. & 4.60 & .718 & - & - & - & - & 0.797 \\
\hline $\begin{array}{l}\text { When it comes to purchasing clothing, I try to get the best or } \\
\text { make the perfect choice. }\end{array}$ & 4.39 & .628 & - & - & - & - & 0.691 \\
\hline In general, I try to buy the best overall quality in clothing. & 4.24 & .734 & - & - & - & - & 0.820 \\
\hline I make a special effort to choose the very best quality clothing. & 4.20 & .665 & - & - & - & - & 0.736 \\
\hline My standards and expectations for clothing I buy are very high. & 3.90 & .542 & - & - & - & - & 0.609 \\
\hline Construct 6: Consumers who are confused by over-choice & 3.33 & - & 0.897 & 0.97 & 0.96 & 0.03 & - \\
\hline $\begin{array}{l}\text { There are so many brands to choose from that I often feel } \\
\text { confused. }\end{array}$ & 3.46 & .739 & - & - & - & - & 0.791 \\
\hline Sometimes, it's hard to choose which store to shop at. & 3.39 & .802 & - & - & - & - & 0.865 \\
\hline $\begin{array}{l}\text { The more I learn about clothing, the harder it seems to choose } \\
\text { the best. }\end{array}$ & 3.46 & .767 & - & - & - & - & 0.828 \\
\hline All the information I get on different products confuses me. & 3.05 & .780 & - & - & - & - & 0.832 \\
\hline Construct 7: Habitual, brand-loyal consumers & 3.54 & - & 0.835 & 0.95 & 0.94 & 0.06 & - \\
\hline I have favourite brands I buy over and over. & 3.65 & .684 & - & - & - & - & 0.790 \\
\hline Once I find a brand of clothing I like, I stick to it. & 3.46 & .719 & - & - & - & - & 0.818 \\
\hline I go to the same stores each time I shop for clothing. & 3.13 & 688 & - & - & - & - & 0.774 \\
\hline
\end{tabular}

Note: Likert scales scores: 1 = Strongly disagree; 3 = Moderately agree; 5 = Strongly agree

AVE, Average variance reliability; CR, Composite reliability.

$\dagger$, Cronbach's $\alpha$ values were computed using SPSS (version 21.0).

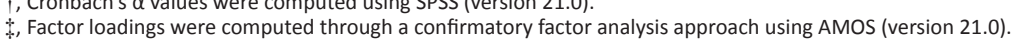

These results provided evidence for acceptable levels of scale reliability. Discriminant validity was established by checking if the lowest AVE value for each construct was greater than the highest shared variance (SV) between constructs (Fornell \& Larcker ibid; Nunnally \& Bernstein 1994). The lowest AVE value was 0.87 , which is greater than the highest shared 
variance between the constructs of 0.22 , thus providing evidence of discriminant validity.

\section{Shopper typologies and age}

In order to compare whether there were any significant differences between the various shopper typologies and age of respondents, a non-parametric alternative of oneway-analysis of variance (ANOVA), the Kruskal-Wallis test, was used. In this instance, scores were converted into ranks and the mean for each group was computed through the SPSS functionality. The Kruskall-Wallis test was deemed appropriate for this study because three categories of Generation Y consumers were being tested simultaneously. These results are reported in Table 3.

Significant differences were only found between Generation $Y$ consumers who were confused by over-choice and age $(p<0.05)$. No significant differences were found between fashion-conscious, hedonistic, brand-conscious, noveltyseeking or habitual, brand-loyal customers and age. Based on this result, Hypothesis $\mathrm{H}_{1}$, which suggests that there are no significant differences between the shopping typologies of the Generation Y cohort and age, is therefore partially rejected.

\section{Discussion}

Factor 1, labelled fashion-conscious consumers, was made up of ten items and accounted for $27.01 \%$ of the variance. The factor had a mean score of 3.86, which indicates agreement towards the various statements on the Likert scale. This result demonstrates that Generation Y consumers accept that they are fashion conscious when purchasing apparel. Fashion consciousness reflects an inclination towards innovative products and a motivation to keep up to date with new styles and fashion trends. Consistent with the findings of the present study, Bakewell, Mitchell and Rothwell (2006) reported that Generation Y consumers are typically very fashionable since they like to buy new and fashionable goods to make themselves visibly fashionable. An earlier study by Bakewell and Mitchell (2003) amongst UK consumers found that both adult and younger female Generation $Y$ buyers appear to be interested in fashion. In addition, they have a desire to bolster their self-esteem through having a 'cool' look by being fashionable. Another study conducted on female consumers by Hou and Lin (2004) demonstrates similar attitudes, reporting that Taiwanese Generation Y females are in general very fashionable: they like to buy new and fashionable goods in order to appear noticeably more fashionable. It is an important supposition, then, that fashion consciousness is a dominant trait amongst Generation $Y$ consumers in South Africa.

Factor 2 was labelled hedonistic consumers, consisted of eight variables and accounted for $11.2 \%$ of the variance. The factor attained a mean score of 3.11, which reflects an inclination towards a moderate position on the Likert scale. This result illustrates that respondents find that shopping for fashion apparel is an enjoyable and a pleasant activity. Generally, hedonistic consumers do not feel that shopping is a waste of time. In addition, they gain excitement from the task of shopping, often by buying something new. Hedonic consumers are associated with the recreational shopping consciousness trait and agree that going shopping for clothing is one of the enjoyable activities in their lives, that they enjoy shopping just for the fun of it, that shopping for clothing satisfies their sense of curiosity and that shopping is an adventure for them. In contrast, the study by Leo et al. (2005) amongst Australian Generation Y consumers found no support for this dimension. These authors concluded that shopping is generally perceived as a task rather than leisure and that consumers attribute their lack of interest in shopping to the fact that is a waste of time. However, Jamal et al. (2006) revealed that the primary shopping motivations, especially for clothing, were seen to be both social and utilitarian in nature. Moreover, Radder, Li and Pietersen (2006) found that Chinese Generation Y individuals in South Africa view shopping as a fun activity and do not mind spending time shopping at a variety of stores and malls and purchasing the latest styles of outfits. This disposition is therefore also existent in the Generation Y racial groups that were surveyed in this study, namely Black people, White people, Indian people and Mixed race.

Factor 3 was labelled brand-conscious consumers, consisted of six variables and accounted for $9.28 \%$ of the variance. The factor had a mean score value of 3.67 , which denotes that respondents were in agreement with the notion that they are brand conscious when shopping for fashion apparel. As mentioned before (refer to Table 1), this dimension measures consumers' orientation towards purchasing well-known and high-priced brands. Respondents who scored highly on this factor appear to equate higher prices with better

TABLE 3: Kruskal-Wallis test: Shopper typologies and age.

\begin{tabular}{|c|c|c|c|c|c|}
\hline \multirow[t]{2}{*}{ Shopper typology } & \multirow[t]{2}{*}{$Z$-value } & \multirow[t]{2}{*}{$p$-value } & \multicolumn{3}{|c|}{ Means } \\
\hline & & & $16-20$ years & $21-24$ years & $25-27$ years \\
\hline Fashion-conscious consumers & 0.506 & 0.777 & 3.14 & 3.18 & 3.21 \\
\hline Hedonistic consumers & 4.740 & 0.093 & 2.98 & 3.25 & 3.19 \\
\hline Brand-conscious consumers & 1.467 & 0.480 & 3.67 & 3.71 & 3.57 \\
\hline Novelty-seeking consumers & 0.986 & 0.611 & 3.53 & 3.56 & 3.40 \\
\hline Quality-conscious consumers & 4.783 & 0.091 & 4.28 & 4.38 & 3.94 \\
\hline Consumer confused by over-choice & 6.123 & $0.047^{*}$ & 3.21 & 3.58 & 3.18 \\
\hline Habitual, brand-loyal consumers & 0.968 & 0.616 & 3.41 & 3.30 & 3.23 \\
\hline
\end{tabular}

*, Significance level $p<0.05$ 
quality. Kwan, Yeung and Au (2004) observed that brandconscious consumers are more likely to purchase expensive international clothing labels that are fashionable. A study conducted by Lysonski, Durvasula and Zotos (1996) also found support for brand-conscious consumers amongst various age cohorts, including Generation Y. Studies conducted by Leo et al. (2005) and Hanzaee and Aghasibeig (2008) also revealed that Generation Y consumers were both innovative and brand conscious. In the context of the South African fashion apparel market, it appears that Generation $Y$ consumers have a high affinity to particular brands, which determines their ultimate purchase decisions.

Factor 4 was labelled novelty-seeking consumers, consisted of five variables and accounted for $7.34 \%$ of the variance. The factor had a mean score of 3.52, which suggests that respondents agreed that they like new and innovative products and tend to gain excitement from seeking new fashion products. Item loadings on this dimension indicate that Generation Y consumers are likely to look for novelty in their purchases. These results are also consistent with the findings of a study conducted by Sproles and Sproles (1990), in which novelty-seeking and fashion-conscious consumers resemble perfectionist consumers, but with the important exception that these types of consumers may also have passive and accepting characteristics. Furthermore, noveltyseeking consumers are likely to buy best-selling brands that are the latest in style at expensive stores (Mokhlis 2009). Based on the findings of the present study, it appears that the continuous introduction of innovative products is likely to have a positive stimulus effect on the purchase of fashion apparel by Generation Y consumers in the South African market.

Factor 5 was labelled quality-conscious consumers, consisted of five variables and accounted for $5.41 \%$ of the variance. The mean score of 4.26 attained by this factor demonstrates that the majority of the respondents indicated that quality was their major consideration when making purchase decisions. Respondents who scored highly on this dimension seek to maximise quality and to make the best choice. Typically, quality-conscious consumers take time to shop for the best buy and purchase their favourite brands repeatedly, presumably since these represent perceived quality for them (Bakewell \& Mitchell 2003). These consumers exhibit the perfectionist trait because they take time to shop carefully for the best quality or for the best value for money (Sproles \& Sproles 1990). Consistently similar results were obtained in a study conducted by Hiu et al. (2001), which focused on Chinese consumers. Other scholars (Radder et al. 2006; Tai 2005) also acknowledge the existence of high levels of quality consciousness amongst Generation $Y$ consumers in countries such as Hong Kong, China and South Africa. The findings of the present study are that a large proportion of South African Generation Y consumers still consider quality to be an important determinant of their purchase decisions when buying fashion apparel.
Factor 6 was labelled consumers who are confused by overchoice. This factor consisted of four variables, accounted for $5.21 \%$ of the variance and attained a mean score of 3.33 , which indicates an inclination towards a moderate position on the Likert scale. Respondents who scored high on this characteristic perceive that the plethora of stores and variety confuses them, making it difficult for them to arrive at the correct buying decision. In addition, product variety and product-related information available to consumers often confuse them. However, the combined traits of confusion and saving of time and money are not necessarily a very important factor amongst Generation Y consumers (Bakewell \& Mitchell 2003). As revealed by Walsh, Mitchell and Hennig-Thurau (2001), consumers who are confused by over-choice are likely to experience information overload and, as a consequence, may be less able to make optimal choices. Gonen and Ozmete (2006) also report that consumers were indecisive in terms of selecting the store to shop at and had difficulties in selecting the products to buy owing to over-choice and often indulged in careless shopping that they later regretted. Contradictory findings were reported by Leo et al. (2005), where consumers from Western cultures were shown to be more focused on specific products, compared with consumers from Eastern cultures. Therefore, this study endorses the notion that there is a proportion of Generation Y consumers in South Africa who find it difficult to select the shop from which to purchase their apparel, given the wide assortment of available brands.

Factor 7 was labelled habitual, brand-loyal consumers, consisted of three variables and accounted for $5.13 \%$ of the variance. The mean score value of $\mathbf{3 . 5 4}$ attained by the factor illustrates that most respondents agreed that they were habitual, brand-loyal consumers. Brand-loyal consumers are those who have favourite brands and stores and have formed habits by choosing them repetitively (Bennett \& Lachowetz 2004). Respondents who scored highly on this dimension identified themselves as consumers who possess strong feelings of loyalty, attaching themselves to a favourite brand. According to Sproles and Sproles (1990), the habitual, brandloyal dimension is associated with serious learning. This suggests that habitual consumer behaviour may emerge from careful learning experiences that lead to positive outcomes, thus reinforcing a repeated buying behaviour pattern, which leads to brand loyalty. The findings of the present study therefore provide credence to the fact that in South Africa, Generation Y consumers of apparel have favourite brands to which they have high degrees of attachment and loyalty.

The Kruskal-Wallis test revealed that differences exist in factor 6 (confused by over-choice) for the age categories: 16-20 years and 25-27 years, and 21-24 years and 25-27 years. Respondents who were in the category of 16-20 years of age $(\bar{x}=4.28)$ were more confused by over-choice than those in the age category of $25-27$ years $(\bar{x}=3.94)$. In addition, respondents who were in the category of 21-24 years of age were more confused by over-choice $(\bar{x}=4.38)$ than those respondents who were in the category 25-27 years of age $(\bar{x}=3.94)$. These findings indicate that younger Generation 
Y consumers in South Africa are more confused by overchoice than those who are relatively older. Previous research findings (Bakewell \& Bakewell 2003) concur that younger consumers tend to experience confusion over their purchase choices. Leo et al. (2005) attribute this response to the fact that consumers are often inundated with information and have to contend with the desire to be innovative and more open to change in their purchase decisions. Younger consumers may be unable to cope with this overwhelming avalanche of information, leading to their manifest confusion in their purchase decisions.

\section{Limitations and implications for further studies}

The selection of mall and shopping centre contexts and the restricted size of the sample are both limitations of the current study in terms of generalisation of the results to other regions and contexts. Whilst the dimensions that were extracted on shopper typologies were in congruence with studies undertaken in Western countries, taking into account the fact that South Africa consists of different submarkets that have distinct characteristics, it would also be unrealistic to generalise the findings revealed in the study to other shopping malls and other areas in the country. In line with this view, similar studies could be replicated in other provinces in order to test the relevance and reliability of the scale. Additionally, the findings of the study are limited to the Generation Y age cohort only. As such, future research should accommodate other generational cohorts such as Generation X so that valuable information may be obtained to segment markets and to develop appropriate marketing strategies. The fact that the findings of the current study are restricted to the fashion apparel market is also acknowledged. This presents an impetus for researchers to extend their future studies to other product types that require extended decision making, such as highly priced products like real estate or motor vehicles.

Another limitation is that the current study employed a non-probability (convenience) sampling method to select the respondents, since it was difficult to obtain a sample frame of Generation Y consumers to participate in the study. This increased the study's susceptibility to high levels of sampling bias (Whitley \& Kite 2009). Furthermore, since the study was based purely on the quantitative approach, significant opportunities to investigate shopper typologies using a qualitative or phenomenological approach seem to be available and could be employed in future research, in order to refine the results. The current study was also conducted using the cross-sectional mode. Future studies could be conducted using longitudinal research, so that variations in shopper typologies amongst the Generation $Y$ cohort could be captured at different periods in time. This could provide a platform to use meta-analysis to benchmark the findings of the studies that were conducted at different periods of time. It also has to be noted that shopper typologies are not limited to the dimensions examined in this study. It would be interesting, then, to explore other underpinning issues as well as structural relationships that are involved in the various sub-elements of shopper typologies.

\section{Conclusion and managerial implications}

This study focused on exploring the shopper typologies of Generation Y consumers and on determining the influence of age in the shopping orientations. The study identified seven pertinent dimensions that characterise the shopping orientations of the Generation Y cohort. It emerged that Generation Y consumers are quality conscious, brand conscious, novelty seekers, hedonistic, confused by overchoice, habitual and brand loyal and fashion conscious. In terms of the influence of age in the shopper typologies, it was observed that younger Generation $\mathrm{Y}$ consumers tend to be more confused by over-choice than those who are relatively older.

The outcomes of the study have several research and managerial implications. This research contributes to the extant literature by giving realistic evidence on the shopping behaviour of the Generation Y cohort used in the study. Secondly, results of this study bring forth the important Generation Y consumer typologies which may further clarify this segment of the market. As such, future researchers on the same subject may use this study as a reference point. The findings may add value to fashion apparel retailers by assisting them to better understand the Generation $Y$ typologies and their characteristics. Subsequently, retail managers may be able to develop marketing strategies that appeal to the Generation Y consumers in this region. The shopper typologies identified in this study can be utilised by apparel store marketers to better understand the Generation $Y$ segment of the market and use the seven dimensions to segment markets and develop specific, tailor-made communication strategies.

\section{Recommendations}

Several recommendations may be made based on the findings of the study. To meet the shopping needs of Generation $Y$ consumers, retailers should emphasise their well-known brand names and set prices at levels that allow consumers to perceive the quality of the product by its price. In addition, retailers should focus on diverse designs, sizes and colours in their product assortment and range. The introduction of new products through the use of fashion shows, fashion magazines and advertisements may provide added advantages in terms of brand awareness.

Since the study revealed that shopping is a form of leisure and enjoyment for Generation Y consumers, retailers should consider strategies that induce a feeling of fun and leisure in consumers. Bakewell and Mitchell (2003) suggest the use of cafes and beauty therapies as well as altering the store layout from a free-form boutique layout to a loop (race-track) layout that uses the outer walls of the store to display items (using 
frontal merchandising and suggested outfits) and keeps the middle of the store relatively clutter-free; this could prove to be quite enchanting to consumers.

Since significant differences were noted with regard to factor 6 , confused by over-choice, and age, it is recommended that retailers adopt the use of communication channels that younger Generation Y consumers find easy to understand. For instance, retailers may simplify marketing messages by using bold and bright colours in their advertisements, thereby assisting consumers to make more informed decisions. The adoption and implementation of such strategies obviously has further implications on meeting organisational goals in areas such as sales and profit maximisation.

\section{Acknowledgements}

The authors appreciate the invaluable suggestions made by the editors and the anonymous reviewers in improving and extending the domain of this article.

\section{Competing interests}

The authors declare that they have no financial or personal relationship(s) that may have inappropriately influenced them in writing this article.

\section{Authors' contributions}

C.M. (Vaal University of Technology) conducted the language revisions and wrote the methodology and results sections. M.D. (Vaal University of Technology) performed the statistical analysis and interpretation, and wrote the limitations, conclusions and recommendations sections. L.M. (Vaal University of Technology) wrote the introduction and literature review sections and collected the data.

\section{References}

Aldlaign, A.H. \& Buttle, F.A., 2002, 'SYSTRA-SQ: A new measure of bank service quality', Industrial Journal of Service Industry Management 13, 362-381. http:// dx.doi.org/10.1108/09564230210445041

Anderson, J.C. \& Gerbing, D.W., 1998, 'Structural equations modelling in practice: A review and recommended two-step approach', Psychological Bulletin 103(3), 411-423. http://dx.doi.org/10.1037/0033-2909.103.3.411

Bae, S., 2004, 'Shopping pattern differences of physically active Korean and American university consumers for athletic apparel', doctoral thesis, College of Education, Florida State University.

Bakewell, C. \& Mitchell, V.W., 2003, 'Generation Y female consumer decision-making styles', International Journal of Retail \& Distribution Management 3(2), 95-106. http://dx.doi.org/10.1108/09590550310461994

Bakewell, C. \& Mitchell, V.W., 2004, 'Male consumer decision-making styles', International Review of Retail, Distribution and Consumer Research 14(2), 223240. http://dx.doi.org/10.1080/0959396042000178205

Bakewell, C., Mitchell, V.W. \& Rothwell, M., 2006, 'UK Generation Y male fashion consciousness', Journal of Fashion Marketing and Management 10(2), 169-180. http://dx.doi.org/10.1108/13612020610667487

Bennett, G. \& Lachowetz, T., 2004, 'Marketing to lifestyles: Action sports and Generation Y', Sports Marketing 13(4), 239-243.

Blackwell, R.D., Miniard, P.W. \& Engel, J.F., 2006, Consumer behaviour, 10th edn., Thomson Learning, Connecticut.

Bowles, J., 2012, 'The best days to hit shopping's hot spots', Themediaonline, 07 March, viewed 06 February 2013, from http://themediaonline.co.za/2012/03/ the-best-days-to-hit-shoppings-hot-spots/

Branchik, B.J., 2010, 'Silver dollars: The development of the US elderly market segment', Journal of Historic Research in Marketing 2(2), 174-189. http://dx.doi. org/10.1108/13612020610667487
Bush, A., Martin, C. \& Bush, V., 2004, 'Sports celebrity influence on the behavioral intentions of Generation Y', Journal of Advertising Research 44, 108-118. http:// intentions of Generation $\mathrm{Y}$, Journal of Ad
dx.doi.org/10.1017/S0021849904040206

Cant, M., Brink, A. \& Brijball, S., 2006, Consumer behaviour, 2nd edn., Juta \& Co., Cape Town.

Chaston, I., 2009, Boomer marketing, Routledge, London.

City of Ekurhuleni, 2011, 10 year history of Ekhuruleni, viewed 05 February 2013, from http://www.ekurhuleni.gov.za/about-ekurhuleni/history-of-ekurhuleni

Cortes, R., 2004, 'Generation wars', Caribbean Business 32(4), 18-22.

Da Silva, R., Davies, G. \& Naude, P., 2002, 'Assessing the influence of retail buyer variables on the buying decision-making process', European Journal of Marketing 36(11), 1297-1327.

DeVellis, R.F., 2003, Scale development: theory and applications, Sage, Thousand Oaks, CA. PMid: 14558062

Dhurup, M., 2008, 'A generic taxonomy of shopping motives among hypermarkets (hyper-stores) customers and the relationship with demographic variables', Acti Commercii 8, 64-79.

Drakes-Bridges, E. \& Burgess, B., 2010, 'Personal preferences of tween shoppers', Journal of Fashion Marketing and Management 14(4), 624-633. http://dx.doi. org/10.1108/13612021011081788

Durvasula, S., Lysonski, S. \& Andrews, C.J., 1993, 'Cross-cultural generalizability of a scale for profiling consumer shopping styles', Journal of Consumer Affairs 27(1), 55-65. http://dx.doi.org/10.1111/j.1745-6606.1993.tb00737.x

Everett, B.S., 1975, 'Multivariate analysis: The need for data and other problems', British Journal of Psychiatry 126, 237-240. http://dx.doi.org/10.1192/ bjp.126.3.237

Fan, J.X. \& Xiao, J.J., 1998, 'Consumer decision-making styles of young adult Chinese', The Journal of Consumer Affairs 32(2), 275-294. http://dx.doi. org/10.1111/j.1745-6606.1998.tb00410.x

Fornell, C. \& Larcker, D., 1981, 'Structural equations models with unobservable variables and measurement error', Journal of Marketing Research 18(1), 39-50. $\mathrm{http}: / / \mathrm{dx}$.doi.org/10.2307/3151312

Foxall, G., 2005, Understanding consumer choice, Palgrave Macmillan, Basingstoke. http://dx.doi.org/10.1057/9780230510029

Fraering, M. \& Minor, M.S., 2006, 'Sense of community: An exploratory study of US consumers of financial services', International Journal of Bank Marketing 24(5), 284-306. http://dx.doi.org/10.1108/02652320610681738

Gehrt, K.C. \& Shim, S., 1998, 'A shopping orientation's segmentation of French consumers: Implications for catalog marketing', Journal of Interactive Marketing 12(4), 34-46. http://dx.doi.org/10.1002/(SICI)1520-6653(199823)12:4<34::AIDDIR4>3.0.CO;2-O

Gonen, E. \& Ozmete, E., 2006, 'Decision-making styles of young Turkish consumers', Journal of Home Economics 13(1), 26-33.

Gupta, M., Brantley, A. \& Vanessa, P.J., 2010, 'Product involvement as a predictor of Generation Y consumer decision making styles', The Business Review 14(2), 28-33.

Gutman, J. \& Mills, M.K., 1982, 'Fashion life style, self-concept, shopping orientation and store patronage: An integrative analysis', Fashion Life Style 58(2), 64-83.

Hafstrom, J.L., Chae, J.S. \& Chung, Y.S., 1992, 'Consumer decision-making styles: Comparison between United States and Korean young consumers', The Journal of Consumer Affairs 26(1), 146-158. http://dx.doi.org/10.1111/j.1745-6606.1992. tb00020.x

Hair, J.F., Black, B., Babin, B., Anderson, R.E., Tatham, R.L. \& Black, W.C., 2010, Multivariate data analysis: A global perspective, Pearson Education Inc., New York.

Hanzaee, K.H. \& Aghasibeig, S., 2008, 'Generation Y female and male decision-making styles in Iran', Distribution and Consumer Research 18(5), 521-537. http://dx.doi. org/10.1080/09593960802573443

Hiu, A., Siu, N., Wang, C.C.L. \& Chang, L.M.K., 2001, 'An investigation of decisionmaking styles of consumers in China', Journal of Consumer Affairs 35(2), 326-345. http://dx.doi.org/10.1111/j.1745-6606.2001.tb00117.x

Hollywood, L.E., Armstrong, G.A. \& Durkin, M.G., 2007, 'Using behavioural and motivational thinking in food segmentation', International Journal of Retail \& Distribution Management 35(9), 691-702. http://dx.doi. org/10.1108/09590550710773246

Hou, C. \& Lin, Z.H., 2004, 'Shopping styles of working Taiwanese females', running paper, National Chung Cheng University, Taiwan.

Hughes, A., 2008, ' $Y$ and how: Strategies for reaching the elusive Generation $Y$ consumer', Honours College Theses, viewed 07 February 2013, from http:// digitalcommons.pace.edu/honorscollege_theses/74

Hulland, J., 1999, 'Use of partial least squares (pls) in strategic management research: A review of four recent studies', Strategic Management Journal 20(2), 195-204. http://dx.doi.org/10.1002/(SICI)1097-0266(199902)20:2<195::AIDSMJ13>3.0.CO;2-7

Jackson, L. Ervin, K., Gardner, P.D. \& Schmitt, N., 2001, 'Gender and the Internet: Women communicating and men searching', Sex Roles 44(5/6), 363-379. http:// dx.doi.org/10.1023/A:1010937901821

Jamal, A., Davies, F., Chudry, F. \& Al-Marri, M., 2006, 'Profiling consumers: A study of Qatari consumers shopping motivations', Journal of Retailing and Consumer Services 13, 67-80. http://dx.doi.org/10.1016/j.jretconser.2005.08.002

Jin, B. \& Kim, J.O., 2003, 'A typology of Korean discount shoppers: Shopping motives, store attributes, and outcomes', International Journal of Service Industry Management 14(4), 396-419. http://dx.doi.org/10.1108/09564230310489240 
Kaltcheva, V. \& Weitz, B., 2006, 'When should a retailer create an exciting store environment?' Journal of Marketing 70(1), 107-118. http://dx.doi.org/10.1509/ environment?' Jour

Kennedy, L., 2001, 'The up and coming generation', Retail Merchandising 41(8), 66-73.

Kim, E.Y. \& Kim, Y., 2004, 'Predicting online purchase intentions for clothing products, European Journal of Marketing 38, 883-897. http://dx.doi. org/10.1108/03090560410539302

Kim, J., 2003, 'College students' apparel impulse buying behaviours in relation to visual merchandising', unpublished master's thesis, Graduate Faculty, University of Georgia, Athens, GA.

Kim, J. \& Park, J., 2005, 'A consumer shopping channel extension model: Attitude shift toward the online store', Journal of Fashion Marketing and Management 9(1), 106-121. http://dx.doi.org/10.1108/13612020510586433

Kinley, T.R., Josiam, B.M. \& Lockett, F., 2010, 'Shopping behavior and the involvement construct', Journal of Fashion Marketing and Management 14(4), 562-575. construct', Journal of Fashion Marketing and
http://dx.doi.org/10.1108/13612021011081742

Kothari, C.R., 2009, Research methodology: Methods and techniques, 2nd edn., New Age International, New Delhi.

Kotler, P., 2003, Marketing management, 11th edn., Prentice Hall, Upper Saddle River NJ. PMCid:PMC2173688

Koutras, E., 2006, 'The use of mobile phones by Generation Y students at two universities in the city of Johannesburg', master's dissertation, Graduate School of Business University of South Africa, Pretoria.

Kwan, C.Y., Yeung, K.W. \& Au, K.F., 2004, 'Decision-making behaviour toward casual wear buying: A study of young consumers in mainland China', Journal of Management \& World Business Research 1(1), 1-10.

Kwan, C.Y., Yeung, K.W. \& Au, K.F., 2008, 'Relationship between consumer decision-making styles and lifestyle characteristics: Young fashion consumer in China', Journal of the Textile Institute 99(3), 193-209. http://dx.doi. org/10.1080/00405000701462351

Laermer, R. \& Simmons, M., 2007, Punk marketing, Harper Collins, New York.

Lee, J., 1998, 'Shopping orientations, purchase criteria and consumption patterns as an outcome of the acculturation process among female Korean-American consumers', unpublished doctoral thesis, Graduate Faculty, University of Texas Tech, Texas.

Leo, C., Bennett, R. \& Hartel, C.E.J., 2005, 'Cross-cultural differences in consume decision-making styles', Cross-Cultural Management 12(3), 32-62. http://dx.doi. org/10.1108/13527600510798060

Liljander, V., Polsa, P. \& Van Riel, V., 2009, 'Modelling consumer responses to an apparel store brand: Store image as a risk reducer', Journal of Retailing and Consume Services 16, 281-290. http://dx.doi.org/10.1016/j.jretconser.2009.02.005

Lysonski, S., Durvasula, S. \& Zotos, Y., 1996, 'Consumer decision-making styles: A multi-country investigation', European Journal of Marketing 30(12), 10-21. http:// dx.doi.org/10.1108/03090569610153273

Ma, Y.J. \& Niehm, L.S., 2006, 'Service expectation of older generation Y customers: An examination of apparel retail setting', Journal of Managing Service Quality 16(6), 620-640. http://dx.doi.org/10.1108/09604520610711936

MacCallum, R.C., Widaman, K.F., Zhang, S. \& Hong, S., 1999, 'Sample size in factor analysis', Psychological Bulletin 107, 247-255.

Malhotra, N.K., 2007, Marketing research: An applied orientation, 2nd edn., PrenticeHall, Upper Saddle River, NJ.

Malhotra, N.K., 2009, Marketing research: An applied orientation, 6th edn., PrenticeHall, Eaglewood Cliffs, NJ.

Matsunaga, M., 2010, 'How to factor analyse your data right: Do's and Don'ts and How-to's', International Journal of Psychological Research 3(1), 97-110.

McDonald, W.J., 1993, 'The roles of demographics purchase histories, and shopper decision-making styles in predicting consumer catalog loyalty', Journal of Direct decision-making styles in predicting consumer catalog loyalty', Journ
Marketing 7(3), 55-64. http://dx.doi.org/10.1002/dir.4000070308

McKay, L., 2008, 'The matured endure', Customer Relationship Management 12(11), 40-44.

Mishra, A.A., 2010, 'Consumer decision-making styles and young-adult consumers: An Indian exploration', Isleme Arastirmalari Dergisi 8(2), 45-62.

Mokhlis, S., 2009, 'An investigation of consumer decision-making styles of young adults in Malaysia', International Journal of Business and Management 4(4), 140-155.

Morton, L.P., 2002, 'Targeting Generation Y', Public Relations 47(2), 46-48.

Neal, C., Quester, P. \& Hawkins, D.J., 2004, Consumer behaviour: Implications for marketing strategy, 6th edn., McGraw-Hill, Sydney.

Noble, S.M., Haytko, D.L. \& Phillips, J., 2009, 'What drives college-age Generation Y consumers', Journal of Business Research 62, 617-628. http://dx.doi. org/10.1016/j.jpusres.2008.01.020
Norris, M. \& Lecavalier, L., 2009, 'Evaluating the use of exploratory factor analysis in developmental disability psychological research', Journal of Autism and in developmental disability psychological research', Journal of Autism and
Developmental Disorders 40(1), 8-20. http://dx.doi.org/10.1007/s10803-009Developmental Disorders

Nunnally, J.C. \& Bernstein, I.H., 1994, Psychometric theory, 3rd edn., McGraw-Hill, New York.

Oh, J. \& Fiorito, S.S., 2002, 'Korean women's clothing brand loyalty', Journal of Fashion Marketing and Management 6(3), 206-222. http://dx.doi. org/10.1108/13612020210441328

Parasuraman, A., Zeithaml, V. \& Berry, L., 1988, 'A multiple-item scale for measuring customer perceptions of service quality', Journal of Retailing 64(1), 12-40.

Parker, R.S., Hermans, C.M. \& Schaefer, A.D., 2004, 'Fashion consciousness of Chinese, Japanese and American teenagers', Journal of Fashion Marketing and Management 8(2), 176-186. http://dx.doi.org/10.1108/13612020410537870

Pentecost, R. \& Lynda, A., 2010, 'Fashion retailing and the bottom line: The effects of generational cohorts, gender, fashion fanship, attitudes and impulse buying on fashion expenditure', Journal of Retailing and Consumer Services 17(1), 43-52. http://dx.doi.org/10.1016/j.jretconser.2009.09.003

Pett, M.A., Lackey, N.R. \& Sullivan, J.J., 2003, Making sense of factor analysis: The use of factor analysis for instrument development in health care research, Sage, Thousand Oaks, CA.

Presser, S., Couper, M.P., Lessler, J.T., Martin, J., Rothgeb, J.M. \& Singer, E., 2004, 'Methods for testing and evaluating survey questions', Public Opinion Quarterly 68(1), 109-130. http://dx.doi.org/10.1093/poq/nfh008

Radder, L., Li, Y. \& Pietersen, J.J., 2006, 'Decision-making styles of young Chinese, Motswana and Caucasian consumers in South Africa: An exploratory study', Journal of Family Ecology and Consumer Sciences 34, 20-31.

Radhakrishna, R.B., 2007, 'Tips for developing and testing questionnaires/ instruments', Journal of Extension 45(1), viewed 21 January 2013, from http:// www.joe.org/joe/2007february/tt2.php

Rempel, C., 2009, 'Marketing to different generations', Security Dealer \& Integrator 31(2), 34-36.

Rosenburg, J., 2008, 'Mind your generation', Journal of Property Management 73(6), $41-44$.

Schewe, C. \& Meredith, G., 2004, 'Segmenting global markets by generational cohorts: Determining motivations by age', Journal of Consumer Behaviour 4, 51-63. http:// dx.doi.org/10.1002/cb.157

Schiffman, L.G. \& Kanuk, L.L., 2010, Consumer behaviour, 10th edn., Prentice-Hall, Upper Saddle River, NJ.

Schwartz, B., 2004, The paradox of choice: Why more is less, Ecco, New York.

Shoham, A. \& Dakalas, V., 2003, 'Family consumer shopping in Israel: The role of teens and parents', Journal of Consumer Marketing 20(3), 238-251. http://dx.doi. org/10.1108/07363760310472263

Sproles, E.K. \& Sproles, G.B., 1990, 'Consumer decision-making styles as a function of individual learning styles', The Journal of Consumer Affairs 24(1), 134-147. http:// dx.doi.org/10.1111/j.1745-6606.1990.tb00262.x

Sproles, G.B. \& Kendall, E.L., 1986, 'A methodology for profiling consumer's decisionmaking styles', The Journal of Consumer Affairs 20(2), 267-279. http://dx.doi. org/10.1111/j.1745-6606.1986.tb00382.x

Tai, S.H.C., 2005, 'Shopping styles of working Chinese females', Journal of Retailing and Consumer Services 12(3), 191-203. http://dx.doi.org/10.1016/j. jretconser.2004.06.003

Truman, R., 2007, 'The why generation', Twelve By Twelve: Forever 21's Upscale Venture, 19 June, viewed 13 February 2013, from http://fashioninvestor.blogspot. com/2007/06/twelveby-twelve-forever-21s-upscale.html

Tustin, D.H., Ligthelm, A.A., Martin, J.H. \& Van Wyk, H.D.J., 2005, Marketing research, University of South Africa, Cape Town.

Valentine, D.B. \& Powers, T.L., 2013, 'Online product search and purchase behavior of Generation Y', Atlantic Marketing Journal 2(1), 122-144.

Walsh, G., Mitchell, V.W. \& Hennig-Thurau, T.H., 2001, 'German consumer decisionmaking styles', The Journal of Consumer Affairs 35(1), 73-95. http://dx.doi. org/10.1111/j.1745-6606.2001.tb00103.x

Westbrook, R.A. \& Black, W.C., 1985, 'A motivation-based shopper typology', Journal of Retailing 61(1), 78-103.

Whitley, B.E. \& Kite, M.E., 2009, The psychology of prejudice and discrimination, Cengage Learning, Hampshire.

Williams, K.C. \& Page, R.A., 2011, 'Marketing to the generations', Journal of Behavioral Studies in Business 3, 1-17.

Zeng, Y., 2008, 'An investigation of decision-making styles of Chinese college student online apparel shoppers', unpublished master's thesis, Graduate Faculty, Louisiana State University and Agricultural and Mechanical College. 